\title{
Synthesis, Characterization and Application of MCM-41@LDH as a New Support for Lysozyme: Central Composite Design to Evaluate Experimental Variables
}

\author{
Forough Karami, Ardeshir Shokrollahi*, (D, Razie Razavizade
}

A precipitation method was used to synthesize MCM-41. Then, the obtained mesoporous was modified using layered double hydroxide (MCM-41@LDH). The novel mesoporous MCM-41@LDH was successfully applied for adsorption of lysozyme (LYS) at different conditions such as adsorbent amount, pH of solution, stirrer time, and concentration of protein which were designed using central composite design (CCD). Furthermore, the chief characteristics of new adsorbent were identified using $X$-ray diffraction (XRD), Fourier transform infrared spectroscopy (FTIR), scanning electron microscopy (SEM) and energy dispersive spectroscopy (EDX) analyses. The maximum adsorption of LYS,

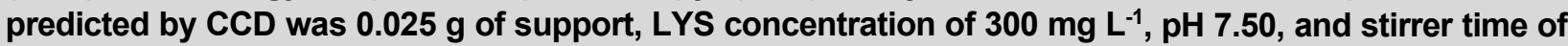
$55 \mathrm{~min}$. The isotherm, kinetic, and thermodynamic equations of LYS on MCM-41@LDH were surveyed. It was established that Freundlich isotherm $\left(R^{2}=0.997\right)$ and second-order kinetic $\left(R^{2}=0.997\right)$ were the best data. Gibbs free energy $\left(\Delta G^{\circ}\right)$, enthalpy $\left(\Delta H^{\circ}\right)$, and entropy $\left(\Delta S^{\circ}\right)$ values were obtained as -17334.5 $\mathrm{kJ} / \mathrm{mol} \mathrm{K}$ (at $298.15 \mathrm{~K}$ ), -17346.3 , and $-0.04 \mathrm{~kJ} / \mathrm{mol}$, respectively. Based on the achieved results including high adsorption intensity of support (Freundlich constant, $n=2.46$ ) and the negative value of $\Delta G^{\circ}$ (spontaneity of the adsorption process), it suggests that MCM-41@LDH should be a favorable candidate for LYS-chromatography and separation applications.

\section{Introduction}

In the recent years, mesoporous materials are the subject of intense research for adsorption, catalysis, and separation, because of high surface area, a large pore volume, high efficiency, high chemical stability, and reusability [1,2]. MCM-41 (Mobil Composition of Matter No. 41) as one of the mesoporous materials is including a hexagonal array, ordered pore structure, and neutral charge. To immobilize proteins and enzymes, such as cytochrome c, trypsin, bovine serum albumin (BSA), and papin, MCM-41 has been recognized as a suitable sorbent owing to its narrow pore size distribution [3-7].

Layered double hydroxides (LDHs) identified as hydrotalcite-like structure or anionic clays have shown a great attraction as they are similar to the traditional interpolation materials [8-11]. The formula of hydrotalcite, $\left[\mathrm{Mg}_{6} \mathrm{Al}_{2}(\mathrm{OH})_{16}\right] \mathrm{CO}_{3} .4 \mathrm{H}_{2} \mathrm{O}$, was introduced by Manasse in 1915 [12]. The LDH structure is defined as layered crystal with extensive diversity affecting by

Chemistry Department, Yasouj University, Yasouj 75918-74831, Iran

${ }^{*}$ Corresponding author:

E-mail: ashokrollahi@mail.yu.ac.ir; Tel: +98743 3223048

DOI: 10.5185/aml.2021.15701 the type of cations, molar ratios of $\mathrm{M}(\mathrm{II}) / \mathrm{M}(\mathrm{III})$, and the nature of anions [13]. The large number of possible components and metal-anion arrangements, good biocompatibility, excellent chemical stability, and $\mathrm{pH}$ dependent solubility makes LDH suitable for many applications such as antimicrobial materials, adsorbents, drug delivery, cosmetic fields, and photo luminescence features $[\mathbf{1 4 , 1 5}]$. On the other hand, high porosity, high surface area, and a lot of active sites allow LDHs to be appropriate for adsorption process. Also, among different nanoparticles, silica is the subject of intense research due to its chemical stability and large number of modifications [16-18]. Numerous researches have been performed for immobilization of enzymes to get increased stability, reutilization, simple separation, and inhibition of corruption in the material $[3-7,19]$. Organic and inorganic nanoparticles for utilizations in biosensors and protein delivery have been developed to immobilize proteins [20]. Specifically, mesoporous silica is attracted great attention as immobilization adsorbent for enzymes [21-24], which maintain its catalytic activity, recyclability, and stability at room temperature for some weeks $[\mathbf{5 , 6}]$.

Lysozyme (LYS) with globular structure containing 129 amino acids cross-linked and four bindings of disulfide is rich in human tears and as a model protein is widely investigated [25]. In the fields of biomedical and 


\section{Advanced \\ Materials Letters https://aml.iaamonline.o}

pharmaceutical, protein chromatography is noteworthy to the effective separation and purification of biomolecules [26]. So, some researchers studied the protein adsorption on different supports.

In the present research, to increase adsorption capacity, MCM-41 was modified via layered double hydroxide (MCM-41@LDH) and then isotherm, kinetic, and thermodynamic parameters of LYS adsorption onto MCM-41@LDH were investigated at various experimental conditions designed via central composite design (CCD).

\section{Materials and methods}

\section{Materials and instruments}

All chemicals and reagents were of analytical grade. Sodium phosphate dodecahydrate $\left(\mathrm{Na}_{3} \mathrm{PO}_{4} \cdot 12 \mathrm{H}_{2} \mathrm{O}\right)$, magnesium nitrate hexahydrate $\left(\mathrm{Mg}\left(\mathrm{NO}_{3}\right)_{2} \cdot 6 \mathrm{H}_{2} \mathrm{O}\right)$, aluminum nitrate nonahydrate $\left(\mathrm{Al}\left(\mathrm{NO}_{3}\right)_{3} .9 \mathrm{H}_{2} \mathrm{O}\right)$, ammonia $\left(\mathrm{NH}_{3}\right)$, MCM-41, cetylmethyl ammonium bromide (CTAB), tetraethyl orthosilicate (TEOS), solutions of $\mathrm{NaOH}$ and $\mathrm{HCl}$ to adjust $\mathrm{pH}$, and ammonium hydroxide $\left(\mathrm{NH}_{4} \mathrm{OH}\right)$ were obtained from Merck Company. LYS powder was purchased from Sigma-Aldrich Company. Water with an electrical resistance of $18 \mathrm{M} \Omega . \mathrm{cm}$ was produced using a system of Milli-Q (Merck Company, Germany).

The morphology properties of MCM-41@LDH were characterized by scanning electron microscopy (SEM) using Zeiss instrument (Sigma VP, England). In addition, energy-dispersive X-ray spectrometry (EDX) of MCM41@LDH was taken to identify elemental analysis (VP1450, Leo, Germany). The structure and phase of working sorbent constituents were investigated using Xray diffraction (XRD, PW 1880, Philips, Amsterdam, Netherland) over $2 \theta$ range of $10.0-80.0^{\circ}$ by $\mathrm{Cu}-\mathrm{K}_{\alpha}$ radiation taken at $40 \mathrm{kV}$ and $40 \mathrm{~mA}$. Agilent Technologies Cary Series $100 \mathrm{UV} / \mathrm{VIS}$ Spectrophotometer was used to record the absorbance of samples at $280 \mathrm{~nm}$. The spectra of samples using Fourier transform infrared spectroscopy (FTIR) were recorded over the range of $4000-400 \mathrm{~cm}^{-1}$ on a 460 FTIR (Jasco, Japan) via a KBr disc.

\section{Preparation of MCM-41@LDH}

\section{Synthesis of MCM-41}

To synthesize MCM-41, $4.000 \mathrm{~g}$ CTAB was dissolved in $1000 \mathrm{~mL}$ ammonium hydroxide $(1.1 \mathrm{M})$ to obtain a clear solution. Then, $16 \mathrm{~mL}$ TEOS, as a source of silicon, drop by drop was added with gentle stirring for $24 \mathrm{~h}$ at room temperature. After that, the product was filtered, washed using $\mathrm{H}_{2} \mathrm{O}$, and dried at room temperature for $48 \mathrm{~h}$, which was caused to formation of MCM-41. To remove CTAB template from structure of MCM-41, the calcination procedure was performed at $823 \mathrm{~K}$ for $24 \mathrm{~h}$ [27-29]. The obtained composite was then modified using LDH.

\section{Synthesis of MCM-41@LDH}

$0.5000 \mathrm{~g}$ MCM-41 was dispersed in $100 \mathrm{~mL} \mathrm{H}_{2} \mathrm{O}$ and was stirred for $10 \mathrm{~min}$. The following is simultaneous addition of $1.000 \mathrm{~g} \mathrm{Mg}\left(\mathrm{NO}_{3}\right)_{2} .6 \mathrm{H}_{2} \mathrm{O}$ and $0.7390 \mathrm{~g} \mathrm{Al}\left(\mathrm{NO}_{3}\right)_{3} .9 \mathrm{H}_{2} \mathrm{O}$ to MCM-41 solution by adjusting $\mathrm{pH} \quad(=10)$ using ammonia and then was stirred for $24 \mathrm{~h}$. The final product was filtered and washed using $\mathrm{H}_{2} \mathrm{O}$ several times. Finally, the filter paper was dried at temperature of $100{ }^{\circ} \mathrm{C}$ to get MCM-41@LDH. Then, the achieved support was identified using FTIR, XRD, SEM, and EDX techniques.

\section{Adsorption experiment}

A $1 \mathrm{mg} / \mathrm{mL}$ stock solution of LYS was dissolved in sodium phosphate buffer $20 \mathrm{mM}$. Then, various protein concentrations in the range of $100-700 \mathrm{mg} \mathrm{L}^{-1}$ were prepared. To survey the adsorption of LYS at room temperature; different concentrations of LYS, amounts of adsorbents, stirrer time, and ranges of $\mathrm{pH}$ were investigated using CCD via the software package DesignExpert version 7.0.0 trial. The desired conditions were described in Tables 1 and 2. For each level, a defined amount of nanomaterial (for example, $0.0400 \mathrm{~g}$ ) was mixed with specified concentration of protein (for example, $10 \mathrm{~mL}, 550 \mathrm{mg} \mathrm{L}^{-1}$ ) under a particular $\mathrm{pH}$ (for example, 4.50) and stirrer time (for example, $135 \mathrm{~min}$ ). After finishing stirrer time, the suspension was centrifuged at $4000 \mathrm{rpm}$ for $20 \mathrm{~min}$ and the obtained supernatant was studied at the $\lambda_{\max }$ of $280 \mathrm{~nm}$ via UV-visible spectrophotometry (Fig. 1). The removal percentage of LYS (R \%) was calculated according to the following equation $[\mathbf{3 0}]$ :

$$
\% R=\frac{\left(C_{0}-C_{e}\right) \times 100}{C_{0}}
$$

where $\mathrm{C}_{0}$ and $\mathrm{C}_{\mathrm{e}}$ are considered as the initial and equilibrium concentration of LYS $\left(\mathrm{mg} \mathrm{L}^{-1}\right)$ which are obtained from Beer-Lambert equation at the $\lambda_{\max }$ of LYS $(280 \mathrm{~nm})$.

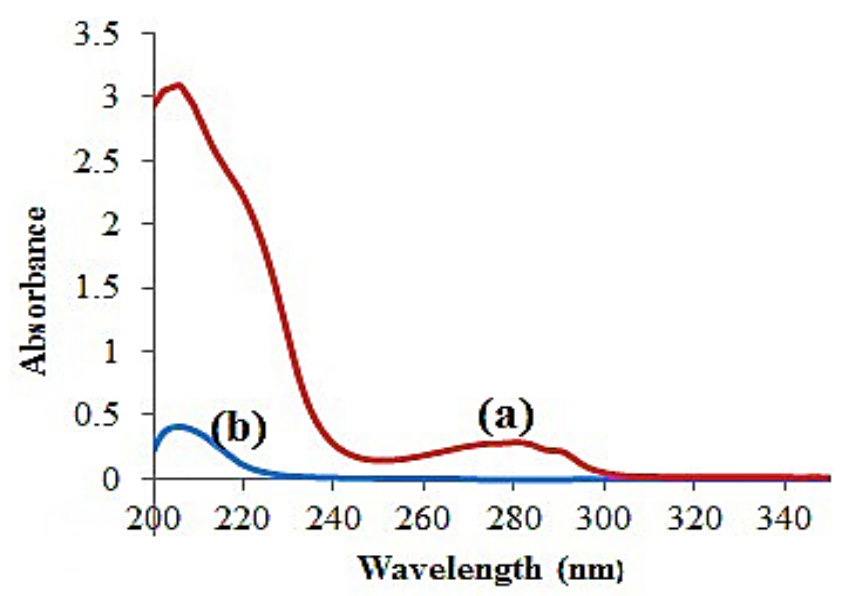

Fig. 1. UV-VIS spectra of LYS before (a) and after (b) adsorption onto MCM-41@LDH (Conditions: LYS concentrations of $250 \mathrm{mg} \mathrm{L}^{-1}, \mathrm{pH}$ 7.50 , support amount of $0.01 \mathrm{~g}$, and stirrer time of $135 \mathrm{~min}$ ). 


\section{Advanced Materials Letters https://aml.iaamonline.o}

\section{LYS adsorption isotherm, kinetic and thermodynamic}

The study of isotherm was performed at room temperature like adsorption experiment (section 2.5) using different concentrations of LYS $\left(150,250,350\right.$, and $\left.500 \mathrm{mg} \mathrm{L}^{-1}\right)$ at $\mathrm{pH} 7.50$, support amount of $0.0250 \mathrm{~g}$, and stirrer time of 55 min. Exception of concentration, other factors were selected according to the acquired optimized conditions.

A typical kinetic experiment was accomplished based on the optimum conditions. The collection of samples was done in time intervals of $2 \mathrm{~min}$ up to $16 \mathrm{~min}$. Then, the samples were collected with time intervals of $15 \mathrm{~min}$ up to $60 \mathrm{~min}$. Finally, after centrifugation, the percent of adsorbed LYS on the MCM-41@LDH was determined using UV-visible spectrophotometry.

In the following, the thermodynamic study of LYS onto MCM-41@LDH was done according to the optimum conditions at various temperatures including 15, 25, 35, and $45^{\circ} \mathrm{C}$.

\section{Experimental design}

Response surface methodology (RSM), described by Box and Wilson, has been used for experimental design to screen and optimize effective factors which are influenced the experiments [31]. In the current research, the software of Design-Expert version 7.0.0 trial for Windows was applied to design and survey relationship among criteria parameters. Analysis of data was accomplished by statistical analysis of variance (ANOVA) and the optimized conditions were identified by coupling this method with desirability function approach and verified using an approval experiment. Three dimensional response surfaces were plotted to visualize the variation of the response versus the terms involved.

\section{Results and discussion}

\section{Characterization of MCM-41@LDH}

Based on the UV-visible spectrum of LYS in Fig. 1, after protein adsorption onto MCM-41@LDH, the peak near $280 \mathrm{~nm}$ was completely disappeared. So, the designed support adsorbed LYS on the surface.

The XRD pattern of MCM-41@LDH to recognize the crystal phases of the nanocomposite has shown on Fig. $\mathbf{2 A}$, which indicates unequal structure due to the contribution of hexagonal structure of MCM-41 and layered structure of LDH. The comparison of diffraction pattern of MCM-41@LDH with MCM-41 [32] and LDH indicated an intense peak at $2 \theta<30^{\circ}, 2 \theta=30-40^{\circ}$, and $2 \theta$ $=55-65$ which demonstrated the formation of mesoporous. Moreover, the peaks of $2 \theta=30-40^{\circ}$ and $2 \theta=60-70^{\circ}$ are related to the formation of $\mathrm{LDH}[33-35]$. The reflection peaks at $23.229^{\circ}, 52.700^{\circ}, 60.445^{\circ}, 67.698^{\circ}$ belong to the (101), (003), (211), (212) planes. Also, according to Alansi's report, JCPDS were mentioned in Fig. 2A [36].

The morphology of MCM-41@LDH was investigated using SEM technique [30]. As shown in Fig. 2B, spherical and agglomerated particles of desired nanocomposite with a diameter of $17.86-67.76 \mathrm{~nm}$ are observed. The average dimensions of nanocomposite were measured by Digimizer version 4.1.1.0. Distribution of nanocomposite, shown as inset, indicated that the most particles are in the range of 20-35 $\mathrm{nm}$. It sounds that the incorporation of $\mathrm{LDH}$ on MCM-41 did not influence the mesoporosity of MCM-41. So, the final structure (MCM-41@LDH) resembles MCM-41 [37].

EDX measurement displays the presence of $\mathrm{Mg}$ at $1.2 \mathrm{keV}$ with intensity of $5 \mathrm{cps} / \mathrm{eV}, \mathrm{Al}$ at $1.4 \mathrm{keV}$ with intensity of $3 \mathrm{cps} / \mathrm{eV}, \mathrm{Si}$ at $1.8 \mathrm{keV}$ with intensity of $7 \mathrm{cps} / \mathrm{eV}, \mathrm{N}$ at $0.15 \mathrm{keV}$ with intensity of $8 \mathrm{cps} / \mathrm{eV}, \mathrm{O}$ at $0.25 \mathrm{keV}$ with intensity of $12 \mathrm{cps} / \mathrm{eV}$, and $\mathrm{Au}$ at $2.2 \mathrm{keV}$ with intensity of $4 \mathrm{cps} / \mathrm{eV}$. Based on the percent weight of $\mathrm{Mg}$ and $\mathrm{Al}$ (14.1\% for $\mathrm{Mg}$ and $8.2 \%$ for $\mathrm{Al})$, a ratio of 1.72 was achieved for $\mathrm{Mg} / \mathrm{Al}$, nearly accordance with actual ratio $(\mathrm{Mg} / \mathrm{Al}=2)($ Fig. $2 \mathrm{C})$.

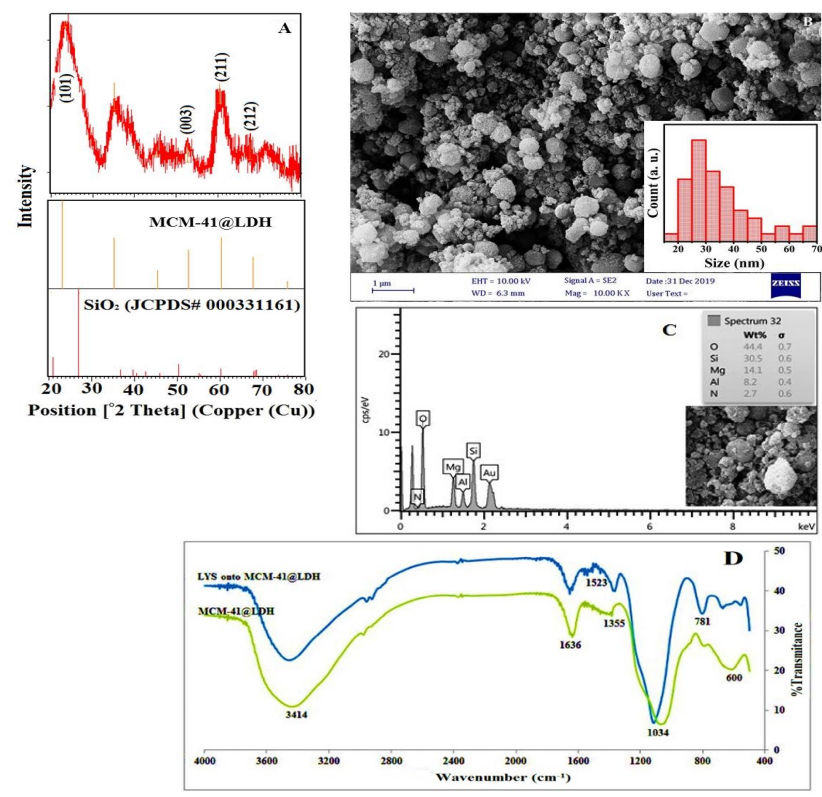

Fig. 2. The XRD pattern of MCM-41@LDH (A), SEM image of MCM41@LDH (B), EDX analysis of MCM-41@LDH (C), and FTIR spectrum of MCM-41@LDH (D).

Fig. 2D demonstrates the FTIR spectra of modified MCM-41 before and after LYS adsorption. In two features based on Shafe's report [34], the absorption peaks around at 1034 and $600 \mathrm{~cm}^{-1}$ are related to MCM-41. The band at $1034 \mathrm{~cm}^{-1}$ is due to the $\mathrm{Si}-\mathrm{O}$ stretching band and is recognized as the fingerprint region of MCM-41 [38]. The wide absorption band at $3414 \mathrm{~cm}^{-1}$ confirms the stretching vibration of $\mathrm{Si}-\mathrm{OH}$ and the presence of $\mathrm{H}_{2} \mathrm{O}$ in the interior layer space of LDH [33]. Regard to FTIR spectrum of LYS [33,39], the amide bands of LYS in the spectrum of LYS onto MCM-41@LDH can be recognized at 1636 and $1523 \mathrm{~cm}^{-1}$ which are associated to $\mathrm{C}=\mathrm{O}$ stretching mode $\left(1636 \mathrm{~cm}^{-1}\right)$, the bending and stretching vibrations of $\mathrm{N}-\mathrm{H}$ and $\mathrm{C}-\mathrm{N}\left(1523 \mathrm{~cm}^{-1}\right)$. The absorption peak at $781 \mathrm{~cm}^{-1}$ in the spectrum of LYS onto MCM-41@LDH could be 


\section{Advanced \\ Materials Letters \\ https://aml.iaamonline.o}

attributed to out of page bending vibration of $\mathrm{N}-\mathrm{H}$ in structure of LYS, which did not indicate in adsorbent structure. The peaks around at 1636 and $1355 \mathrm{~cm}^{-1}$ are attributed to the vibrations of $\mathrm{NO}_{3}{ }^{-}$which overlap with the amide bands of LYS. Also, the bending vibration of $\mathrm{H}-\mathrm{OH}$ in $\mathrm{H}_{2} \mathrm{O}$ at $1636 \mathrm{~cm}^{-1}$ showed an overlapping with vibration of nitrate anion. After LYS adsorption, the signals of $3414,1634,1355$, and $600 \mathrm{~cm}^{-1}$ decreased, which means LYS has taken part in the adsorption process.

\section{Central composite design}

As shown in Table 1, a CCD was applied to adjust four variables including $\mathrm{pH}$, concentration of protein, amount of adsorbent, and time of stirrer. 30 experiments were done based on the experimental program. Characteristics of each level and its responses were presented in Table 2. ANOVA shown in Table $\mathbf{3}$ expresses the significant of designed model and the chief interactions of between variables. The amount of F-value (Table 3) for Model (184.89) means the model is significant. Values of $\mathrm{p}$-value less than 0.0500 indicate the model terms are significant. In this case $\mathrm{A}, \mathrm{B}, \mathrm{C}, \mathrm{D}$, $\mathrm{AB}, \mathrm{BC}, \mathrm{A}^{2}, \mathrm{~B}^{2}$, and $\mathrm{C}^{2}$ are significant model terms. The F-value for Lack of Fit (3.01) implies the Lack of Fit is not significant relative to the pure error. The predicted R-Squared of 0.970 is in reasonable agreement with the adjusted R-Squared of 0.988 (Table 4) and shows a high dependence and correlation between the obtained and the expected values of response. The high value of adequated precision (41.093) as the signal to noise ratio is desirable. So, the value of 41.093 indicates an adequate signal. Finally, a quadratic equation was achieved via the coefficients values, which is as follows:

$\mathrm{R}=60.51438+8.86479 \mathrm{~A}+0.027633 \mathrm{~B}+603.70312 \mathrm{C}+$ $0.059444 \mathrm{D}-2.26667 \mathrm{E}-003 \mathrm{AB}-7.66667 \mathrm{AC}-5.20833 \mathrm{E}-$ $003 \mathrm{AD}+2.51083 \mathrm{BC}-1.87500 \mathrm{E}-006 \mathrm{BD}-0.90937 \mathrm{CD}-$ $0.57769 \mathrm{~A}^{2}-1.34102 \mathrm{E}-004 \mathrm{~B}^{2}-21622.91667 \mathrm{C}^{2}-$ $1.32682 \mathrm{E}-004 \mathrm{D}^{2}$

where $\mathrm{R}$ is the adsorption percent of LYS and A, B, C, D are considered as the $\mathrm{pH}$ of mixture, concentration of LYS, amount of adsorbent, and time of stirrer, respectively.

Table 1. Designed factors and limits of levels for response surface quadratic model.

\begin{tabular}{lccc}
\hline \multicolumn{1}{c}{ Factor } & $\begin{array}{c}\text { Low } \\
\text { value }\end{array}$ & $\begin{array}{c}\text { Central } \\
\text { value }\end{array}$ & $\begin{array}{c}\text { High } \\
\text { value }\end{array}$ \\
\hline $\mathrm{pH}$ & 4.50 & 6.00 & 7.50 \\
LYS Concentration $\left(\mathrm{mg} \mathrm{L}^{-1}\right)$ & 250 & 400 & 550 \\
Amount of Adsorbent $(\mathrm{g})$ & 0.015 & 0.030 & 0.035 \\
Stirrer Time (min) & 55 & 95 & 135 \\
\hline
\end{tabular}

Table 2. Experimental conditions from CCD for the adsorption of LYS

\begin{tabular}{|c|c|c|c|c|c|c|}
\hline Run & Block & $\mathrm{pH}$ & $\begin{array}{c}\text { LYS } \\
\text { Concentration } \\
\left(\mathrm{mg} \mathrm{L}^{-1}\right)\end{array}$ & $\begin{array}{l}\text { Amount of } \\
\text { Adsorbent } \\
\text { (g) }\end{array}$ & $\begin{array}{c}\text { Stirrer } \\
\text { Time } \\
(\mathrm{min})\end{array}$ & $\begin{array}{c}\text { Response } \\
(\%)\end{array}$ \\
\hline 1 & Block 1 & 4.50 & 550.00 & 0.040 & 135.00 & 97.00 \\
\hline 2 & Block 1 & 4.50 & 250.00 & 0.040 & 135.00 & 99.06 \\
\hline 3 & Block 1 & 7.50 & 250.00 & 0.010 & 135.00 & 100.00 \\
\hline 4 & Block 1 & 7.50 & 550.00 & 0.010 & 55.00 & 82.63 \\
\hline 5 & Block 1 & 7.50 & 550.00 & 0.010 & 135.00 & 82.00 \\
\hline 6 & Block 1 & 6.00 & 400.00 & 0.030 & 175.00 & 100.00 \\
\hline 7 & Block 1 & 6.00 & 100.00 & 0.030 & 95.00 & 99.00 \\
\hline 8 & Block 1 & 7.50 & 550.00 & 0.040 & 55.00 & 100.00 \\
\hline 9 & Block 1 & 4.50 & 250.00 & 0.010 & 135.00 & 97.90 \\
\hline 10 & Block 1 & 4.50 & 250.00 & 0.040 & 55.00 & 100.00 \\
\hline 11 & Block 1 & 7.50 & 550.00 & 0.040 & 135.00 & 97.00 \\
\hline 12 & Block 1 & 9.00 & 400.00 & 0.030 & 95.00 & 98.00 \\
\hline 13 & Block 1 & 4.50 & 550.00 & 0.010 & 55.00 & 84.00 \\
\hline 14 & Block 1 & 6.00 & 400.00 & 0.030 & 95.00 & 102.30 \\
\hline 15 & Block 1 & 7.50 & 250.00 & 0.040 & 135.00 & 98.17 \\
\hline 16 & Block 1 & 4.50 & 550.00 & 0.040 & 55.00 & 99.00 \\
\hline 17 & Block 1 & 4.50 & 550.00 & 0.010 & 135.00 & 82.00 \\
\hline 18 & Block 1 & 6.00 & 400.00 & 0.030 & 95.00 & 101.30 \\
\hline 19 & Block 1 & 6.00 & 400.00 & 0.030 & 95.00 & 102.20 \\
\hline 20 & Block 1 & 6.00 & 700.00 & 0.030 & 95.00 & 80.86 \\
\hline 21 & Block 1 & 6.00 & 400.00 & 0.030 & 95.00 & 102.00 \\
\hline 22 & Block 1 & 6.00 & 400.00 & 0.005 & 95.00 & 85.80 \\
\hline 23 & Block 1 & 6.00 & 400.00 & 0.050 & 95.00 & 100.90 \\
\hline 24 & Block 1 & 6.00 & 400.00 & 0.030 & 95.00 & 101.15 \\
\hline 25 & Block 1 & 4.50 & 250.00 & 0.010 & 55.00 & 98.00 \\
\hline 26 & Block 1 & 7.50 & 250.00 & 0.010 & 55.00 & 101.90 \\
\hline 27 & Block 1 & 6.00 & 400.00 & 0.030 & 15.00 & 102.30 \\
\hline 28 & Block 1 & 3.00 & 400.00 & 0.030 & 95.00 & 95.60 \\
\hline 29 & Block 1 & 6.00 & 400.00 & 0.030 & 95.00 & 102.15 \\
\hline 30 & Block 1 & 7.50 & 250.00 & 0.040 & 55.00 & 102.68 \\
\hline
\end{tabular}

Table 3. Analysis of variance (ANOVA) results for response surface quadratic model.

\begin{tabular}{|c|c|c|c|c|c|c|}
\hline Source & $\begin{array}{l}\text { Sum of } \\
\text { Squares }\end{array}$ & D.F $F^{1}$ & $\begin{array}{l}\text { Mean } \\
\text { Square }\end{array}$ & F-Value & $\begin{array}{l}\mathrm{p} \text {-value } \\
\text { Prob }>F\end{array}$ & \\
\hline Model & 1491.51 & 14 & 106.54 & 184.89 & $<0.0001$ & Significant \\
\hline A-pH & 6.22 & 1 & 6.22 & 10.80 & 0.0050 & \\
\hline B- LYS & 507.47 & 1 & 507.47 & 880.71 & $<0.0001$ & \\
\hline $\begin{array}{l}\text { Concentration } \\
\text { C-Amount of } \\
\text { Adsorbent }\end{array}$ & 373.51 & 1 & 373.51 & 648.22 & $<0.0001$ & \\
\hline $\begin{array}{l}\text { D- Stirrer } \\
\text { Time }\end{array}$ & 16.14 & 1 & 16.14 & 28.01 & $<0.0001$ & \\
\hline $\mathrm{AB}$ & 4.16 & 1 & 4.16 & 7.22 & 0.0169 & \\
\hline $\mathrm{AC}$ & 0.21 & 1 & 0.21 & 0.37 & 0.5536 & \\
\hline $\mathrm{AD}$ & 1.56 & 1 & 1.56 & 2.71 & 0.1204 & \\
\hline $\mathrm{BC}$ & 226.95 & 1 & 226.95 & 393.88 & $<0.0001$ & \\
\hline $\mathrm{BD}$ & $\begin{array}{l}2.025 \\
\text { E-003 }\end{array}$ & 1 & $\begin{array}{l}2.025 \\
\text { E-003 }\end{array}$ & $\begin{array}{l}3.514 \\
\text { E-003 }\end{array}$ & 0.9535 & \\
\hline $\mathrm{CD}$ & 2.12 & 1 & 2.12 & 3.67 & 0.0745 & \\
\hline $\mathrm{A}^{2}$ & 46.34 & 1 & 46.34 & 80.42 & $<0.0001$ & \\
\hline $\mathrm{B}^{2}$ & 249.71 & 1 & 249.71 & 433.37 & $<0.0001$ & \\
\hline $\mathrm{C}^{2}$ & 128.24 & 1 & 128.24 & 222.56 & $<0.0001$ & \\
\hline$D^{2}$ & 1.24 & 1 & 1.24 & 2.15 & 0.1637 & \\
\hline Residual & 8.64 & 15 & 0.58 & & & \\
\hline Lack of Fit & 7.41 & 10 & 0.74 & 3.01 & 0.1175 & $\begin{array}{c}\text { not } \\
\text { Significant }\end{array}$ \\
\hline Pure Error & 1.23 & 5 & 0.25 & & & \\
\hline Cor Total & 1500.16 & 29 & & & & \\
\hline
\end{tabular}

Table 4. Obtained values of $\mathrm{R}^{2}$ from CCD analysis.

\begin{tabular}{cc}
\hline R-Squared & 0.994 \\
\hline Adjusted R-Squared & 0.988 \\
Predicted R-Squared & 0.970 \\
Adequated Precision & 41.093
\end{tabular}




\section{Advanced \\ Materials Letters \\ https://aml.iaamonline.o}

In order to understand the acquired results, threedimensional response surface graphs are illustrated in Fig. 3. To realize the best experimental conditions, desirability parameter of 1.0 was selected to the maximum response. So, based on the obtained results and desirability function of 1.0, the $\mathrm{pH}$ value of 7.50, LYS concentration of $300 \mathrm{mg} \mathrm{L}^{-1}$, support amount of $0.0250 \mathrm{~g}$, and stirrer time of 55 min were selected as the optimum condition.

\section{Optimization of variables}

The $\mathrm{pH}$ of solution as one of the effective parameters was investigated over a $\mathrm{pH}$ range of 3.0-9.0 by CCD. The relationship between $\mathrm{pH}$-and LYS concentration, amount of sorbent, and stirrer time were illustrated in Fig. 3(A, B, and $\mathbf{D})$ as three dimensional graphs. Isoelectric point of LYS is $11.0(\mathrm{pI}=11.0)$, providing a positive charge at $\mathrm{pH}$ lower than 11, while the adsorbent surfaces would be negatively charged, making a suitable interaction. As shown in Fig. 3(B and D), the highest adsorption was achieved near the neutral $\mathrm{pH}$. Consequently, via the software optimization selection, $\mathrm{pH}$ of 7.50 was chosen as the optimum $\mathrm{pH}$.

The amount of MCM-41@LDH in adsorption process was studied over a range of 0.0050 up to $0.0500 \mathrm{~g}$ by CCD. As seen from Fig. 3(B), the adsorption percent increases with rising amount of MCM-41@LDH. But, because of agglomeration of adsorbent at the high amounts, the value of $0.0250 \mathrm{~g}$ was suggested as the best weight using the software optimization option.

The minimum and maximum amount of stirrer time was investigated in the range of 15 and $175 \mathrm{~min}$, respectively. From Fig. 3(D), it can be seen that the reducing time from 135 to 55 min provides a high signal. So, the time of $55 \mathrm{~min}$ was selected as the best time for LYS adsorption.

LYS concentration as another parameter was investigated in the range of $100-700 \mathrm{mg} \mathrm{L}^{-1}$. Due to the occupied sites of MCM-41@LDH by LYS, there is the limitation on LYS concentration. So based on Fig. 3 (A and $\mathbf{C}$ ), amount of $300 \mathrm{mg} \mathrm{L}^{-1}$ was obtained as the best concentration.
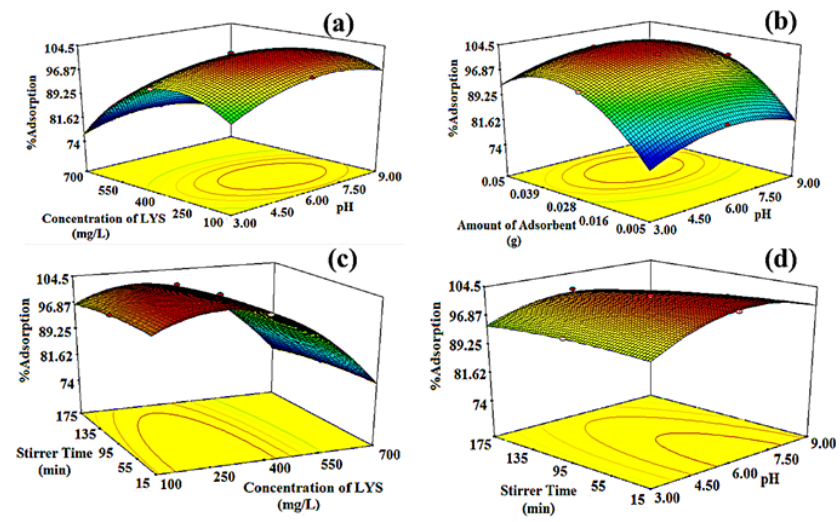

Fig. 3. Three dimensional response surfaces for LYS adsorption. (a) concentration of LYS-pH; (b) amount of adsorbent-pH; (c) stirrer timeconcentration of LYS; (d) stirrer time-pH.
Table 5. Isotherm models for LYS adsorption onto MCM-41@LDH (In optimized conditions).

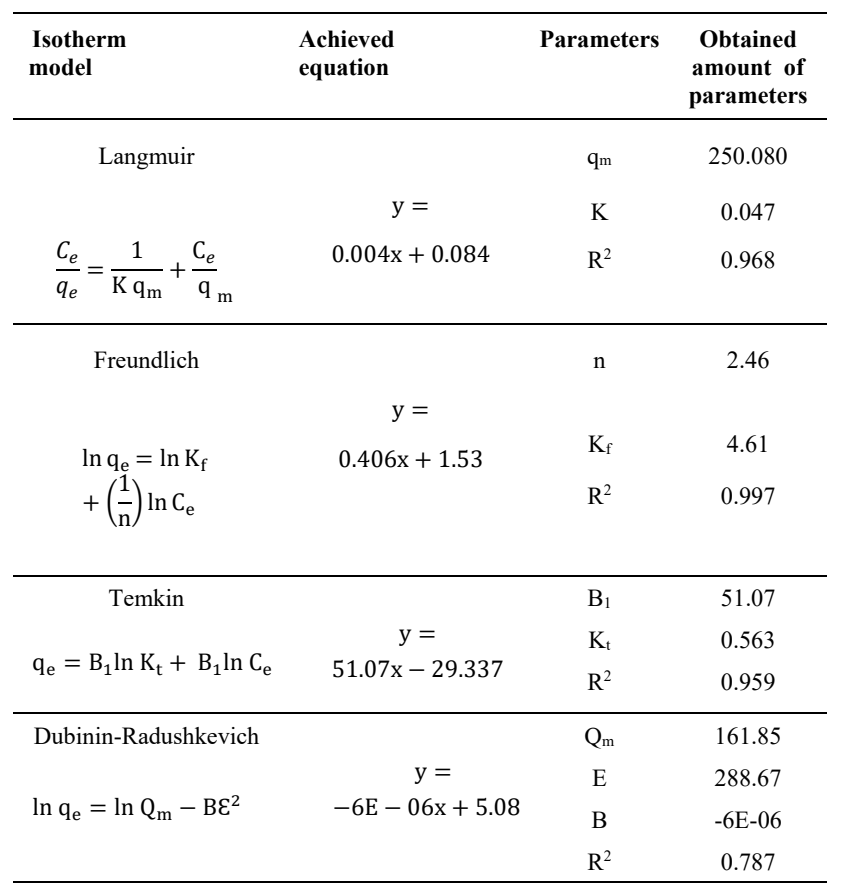

$\mathrm{C}_{\mathrm{e}}$ : LYS concentrations at equilibrium $\left(\mathrm{mg} \mathrm{L}^{-1}\right)$, $\mathrm{q}_{\mathrm{e}}$ : adsorbed LYS amount at equilibrium $\left(\mathrm{mg} \mathrm{g}^{-1}\right), \mathrm{q}_{\mathrm{m}}$ : maximum monolayer adsorption capacity ( $\left.\mathrm{mg} \mathrm{g}^{-1}\right)$, $\mathrm{K}$ : Langmuir constant $\left(\mathrm{L} \mathrm{mg}^{-1}\right), \mathrm{K}_{\mathrm{F}}$ and $\mathrm{n}$ : Freundlich coefficients, $\mathrm{K}_{\mathrm{t}}$ : equilibrium binding constant, $\left(\mathrm{L} \mathrm{mol}^{-1}\right), \mathrm{B}_{1}$ : the constant related to the heat of adsorption, $\mathrm{Q}_{\mathrm{m}}$ : Dubinin-Radushkevich constant $\left(\mathrm{mol} \mathrm{g}^{-1}\right)$, B: related to the mean sorption free energy $\left(\mathrm{kJ} \mathrm{mol}^{-1}\right), \varepsilon$ : surface potential.

\section{LYS adsorption isotherm}

Different isotherm models have been explained to describe the adsorption equilibrium of desired process. In the current research, Langmuir, Freundlich, Temkin, and Dubinin-Radushkevich models were studied to assess the sorption capacity of MCM-41@LDH. Shown in Table 5 are equilibrium equations of LYS adsorption on MCM41@LDH. It is clear that the Freundlich model displayed excellent fit to the experimental results with superior correlation coefficients of 0.997 . It means that the LYS adsorption onto MCM-41@LDH is heterogeneous, because Freundlich model is applied for heterogeneous process. The adsorption energy for Freundlich model depends on the number sites of support, which is occupied by protein or other molcules. The empirical equation of Freundlich is assigned as [30]:

$$
\ln \mathrm{q}_{\mathrm{e}}=\ln \mathrm{K}_{\mathrm{f}}+\left(\frac{1}{\mathrm{n}}\right) \ln \mathrm{C}_{\mathrm{e}}
$$

where $\mathrm{K}_{\mathrm{f}}$ and $\mathrm{n}$ are considered as Freundlich constants. The capacity of adsorption and adsorption intensity of a typical process are identified using $\mathrm{K}_{\mathrm{f}}$ and $\mathrm{n}$ constants, in the order given. The obtained high values of $\mathrm{K}_{\mathrm{f}}$ and $\mathrm{n}$ indicate good adsorption capacity and tendency of the adsorbent for adsorption of LYS. Different isotherm graphs for LYS adsorption on MCM-41@LDH were illustrated in Fig. 4. 

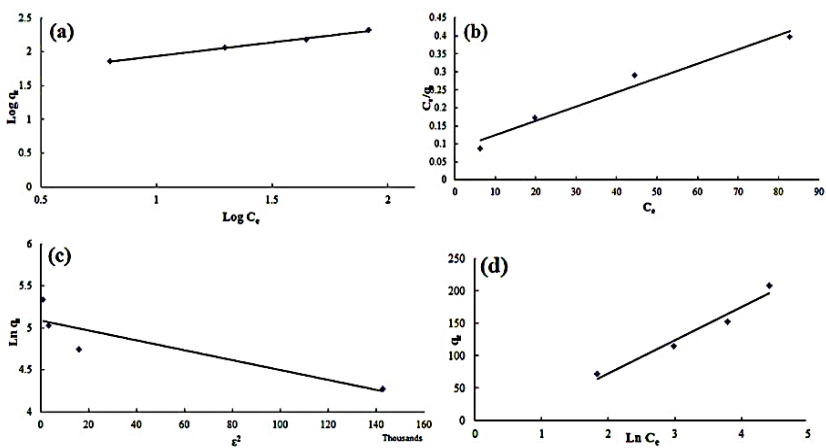

Fig. 4. Freundlich (a), Langmuir (b), Dubinin-Radushkevich (c), and Temkin (d) isotherms for LYS adsorption on MCM-41@LDH (Conditions: LYS concentrations of $\left(150,250,350\right.$, and $\left.500 \mathrm{mg} \mathrm{L}^{-1}\right)$ at $\mathrm{pH} 7.50$, amount of support $0.025 \mathrm{~g}$, and stirrer time of $55 \mathrm{~min}$ ).

Table 6. Kinetic results of LYS on MCM-41@LDH (In optimized conditions).

\begin{tabular}{|c|c|c|c|}
\hline Kinetic model & Achieved equation & Parameters & $\begin{array}{c}\text { Obtained } \\
\text { amount of } \\
\text { parameters }\end{array}$ \\
\hline \multirow{3}{*}{$\begin{array}{l}\text { First-order kinetic } \\
\log \left(q_{e q}-q_{t}\right)= \\
\log q_{e q}-\left(k_{1} / 2.303\right) t\end{array}$} & \multirow{3}{*}{$\begin{array}{l}y= \\
-0.039 x+1.900\end{array}$} & $\begin{array}{c}\mathrm{k}_{1} \\
\left(\mathrm{~min}^{-1}\right)\end{array}$ & 0.090 \\
\hline & & $\begin{array}{c}\mathrm{qeq} \\
\left(\mathrm{mg} \mathrm{g}^{-1}\right)\end{array}$ & 79.500 \\
\hline & & $\mathrm{R}^{2}$ & 0.971 \\
\hline Second-order kinetic & \multirow{3}{*}{$\begin{array}{l}y= \\
0.007 x+0.016\end{array}$} & $\begin{array}{c}\mathrm{k}_{2} \\
\left(\mathrm{~g} \mathrm{mg}^{-1} \min ^{-1}\right)\end{array}$ & 0.003 \\
\hline \multirow[t]{2}{*}{$t / q_{t}=1 / k_{2} \cdot q_{e q}^{2}+t / q_{e q}$} & & $\begin{array}{c}\mathrm{q}_{\mathrm{eq}} \\
\left(\mathrm{mg} \mathrm{g}^{-1}\right)\end{array}$ & 144.920 \\
\hline & & $\mathrm{R}^{2}$ & 0.997 \\
\hline \multirow[t]{2}{*}{ Intra-particle diffusion } & \multirow[b]{2}{*}{$\begin{array}{l}y= \\
13.106 x+62.62\end{array}$} & $\begin{array}{c}\mathrm{K}_{\text {dif }} \\
\left(\mathrm{mg} \mathrm{g}^{-1} \mathrm{~min}^{-0.5}\right)\end{array}$ & 13.106 \\
\hline & & $\begin{array}{l}\mathrm{C} \\
\mathrm{R}^{2}\end{array}$ & $\begin{array}{c}62.620 \\
0.923 \\
\end{array}$ \\
\hline \multirow{2}{*}{$\begin{array}{l}\text { Elovich } \\
q_{t}=\frac{1}{\beta} \ln (\alpha \beta)+\frac{1}{\beta} \ln t\end{array}$} & \multirow{2}{*}{$\begin{array}{l}y= \\
19.95 x+65.32\end{array}$} & $\begin{array}{c}\beta\left(\mathrm{g} \mathrm{mg}^{-1}\right) \\
\alpha\left(\mathrm{mg} \mathrm{g}^{-1} \mathrm{~min}^{-1}\right)\end{array}$ & $\begin{array}{c}0.050 \\
527.16\end{array}$ \\
\hline & & $\mathrm{R}^{2}$ & 0.968 \\
\hline
\end{tabular}

$\mathrm{k}_{1}$ : rate constant of the first-order model $\left(\mathrm{min}^{-1}\right)$, qeq: amount of adsorbed LYS at equilibration time $\left(\mathrm{mg} \mathrm{g}^{-1}\right)$, qt: amount of adsorbed LYS at time $\mathrm{t}\left(\mathrm{mg} \mathrm{g}^{-1}\right)$, $\mathrm{k}_{2}$ : rate constant of the second-order model $(\mathrm{g} / \mathrm{mg} \mathrm{min}), \mathrm{K}_{\text {dif: }}$ intraparticle diffusion rate constant $\left(\mathrm{mg} \mathrm{g}^{-1} \mathrm{~min}^{-0.5}\right), \mathrm{C}$ : intercept, $\alpha$ : initial adsorption rate constant $\left(\mathrm{mg} \mathrm{g}^{-1} \mathrm{~min}^{-1}\right), \beta$ : desorption rate constant $\left(\mathrm{g} \mathrm{mg}^{-1}\right)$.

\section{LYS adsorption kinetic}

The kinetic results are significant in mass transfer process and separation of proteins. Hence, the first-order kinetic, second-order kinetic, intra-particle diffusion, and Elovich models were studied to describe the adsorption mechanism and efficiency of the sorbent. Table 6 displays the LYS sorption kinetic equations and significant parameters. In general, a typical equation for the second-order kinetic model is described using [40]:

$$
\frac{\mathrm{t}}{\mathrm{q}_{\mathrm{t}}}=\frac{1}{\mathrm{k}_{2} \mathrm{q}_{\mathrm{eq}}^{2}}+\frac{1}{\mathrm{q}_{\mathrm{eq}}} \mathrm{t}
$$

where $\mathrm{k}_{2}$ is the rate constant of the second-order kinetic, $\mathrm{q}_{\mathrm{eq}}$ and $\mathrm{q}_{\mathrm{t}}$ are assigned the adsorbed LYS amounts on MCM-41@LDH at time of equilibrium and t, respectively. The plot of $\frac{t}{q_{t}}$ versus time $(\mathrm{t})$ was fitted for a linear relationship, which $\mathrm{k}_{2}$ and $\mathrm{q}_{\mathrm{eq}}$ are defined from slope and intercept of equation, respectively. The experimental $\mathrm{q}_{\mathrm{eq}}$ value was obtained $141.12 \mathrm{mg} \mathrm{g}^{-1}$ which is similar to the theoretical $\mathrm{q}_{\mathrm{eq}}$ value predicted by the second-order kinetic $\left(144.920 \mathrm{mg} \mathrm{g}^{-1}\right)$. Comparsion of the experimental $\mathrm{q}_{\mathrm{eq}}$ (141.12 $\mathrm{mg} \mathrm{g}^{-1}$ ) value with obtained amount from the firstorder kinetic showed a high difference $\left(79.500 \mathrm{mg} \mathrm{g}^{-1}\right)$. Fig. 5 displays the second-order kinetic model for LYS adsorption on MCM-41@LDH. High value of $\mathrm{R}^{2}$ for second-order kinetic is revealed that the process is compatible with the second-order one showing that the LYS adsorption onto MCM-41@LDH is probably the controller step [41]. Also, low amount of rate constant, probably is resulted from heterogeneous structure of adsorbent. Because, LDH structure is defined as layered crystal and MCM-41 is as mesoporous materials with a hexagonal array. The kinetic graphs for LYS adsorption onto MCM-41@LDH were illustrated in Fig. 5.
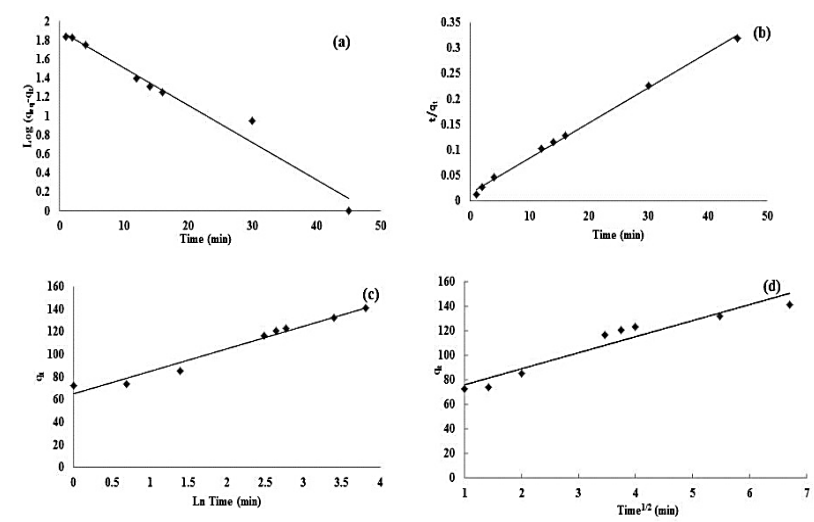

Fig. 5. Adsorption kinetic models for LYS on MCM-41@LDH. Pseudo first-order kinetic (a), pseudo second-order kinetic (b), Elovich (c), intraparticle diffusion (d) (Conditions: LYS concentration of $300 \mathrm{mg} \mathrm{L}^{-1}, \mathrm{pH}$ 7.50 , amount of support $0.025 \mathrm{~g}$, and stirrer time of $55 \mathrm{~min}$. The collection of samples was done in time intervals of $2 \mathrm{~min}$ up to $16 \mathrm{~min}$. Then, the samples were collected with time intervals of $15 \mathrm{~min}$ up to 60 $\min )$.

\section{LYS adsorption thermodynamic}

To identify the spontaneity of the adsorption process, Gibbs free energy $\left(\Delta \mathrm{G}^{\circ}\right)$ was calculated using equations of:

$$
\Delta \mathrm{G}^{\circ}=\Delta \mathrm{H}^{\circ}-\mathrm{T} \Delta \mathrm{S}^{\circ}
$$

and

$$
\Delta \mathrm{G}^{\circ}=-\mathrm{RT} \ln \mathrm{K}
$$

$\Delta \mathrm{H}^{\circ}, \Delta \mathrm{S}^{\circ}$, and $\mathrm{K}$ describe the enthalpy, entropy, and thermodynamic equilibrium constant, respectively. The negative value of $\Delta \mathrm{G}^{\mathrm{o}}$ means a considerable adsorption. The thermodynamic equilibrium constant is the ratio of LYS equilibrium concentration on the MCM-41@LDH to that in solution and is achieved using plotting $\ln \frac{\mathrm{q}_{\mathrm{eq}}}{\mathrm{C}_{\mathrm{eq}}}$ against $\mathrm{q}_{\mathrm{eq}}$ (Fig. 6). Values of $\Delta \mathrm{H}^{\circ}$ and $\Delta \mathrm{S}^{\circ}$ can be identified from the slope and the intercept of the linear graph of $\ln \mathrm{K}$ against 1/T, respectively. 


\section{Advanced Materials Letters https://aml.iaamonline.o}

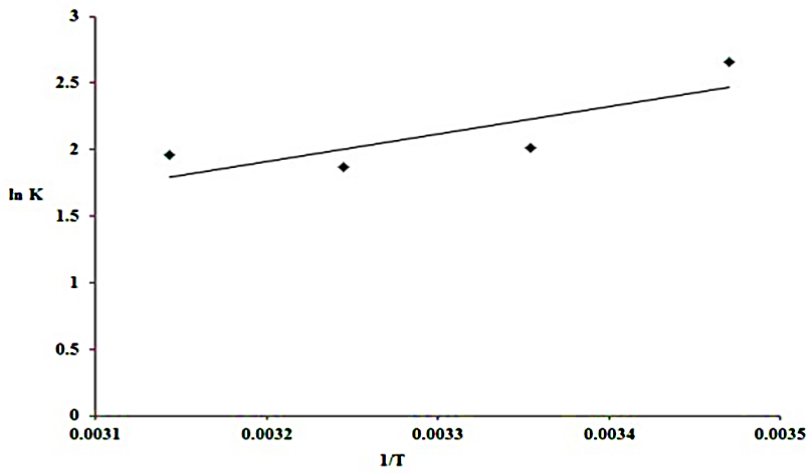

Fig. 6. Adsorption thermodynamic model for LYS on MCM-41@LDH

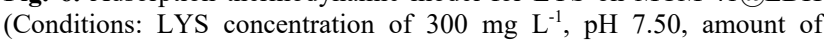
support $0.025 \mathrm{~g}$, and stirrer time of $55 \mathrm{~min}$. The thermodynamic study of LYS was done according to the optimum conditions at various temperatures including $15,25,35$, and $45^{\circ} \mathrm{C}$ ).

Amounts of $\Delta \mathrm{G}^{\circ}, \Delta \mathrm{H}^{\circ}$, and $\Delta \mathrm{S}^{\circ}$ for the adsorption of LYS onto MCM-41@LDH were presented in Table 7. Values of $\Delta \mathrm{H}^{\circ}$ and $\Delta \mathrm{S}^{\circ}$ were achieved as -17346.3 and $-0.04\left(\mathrm{~kJ} \mathrm{~mol}^{-1}\right)$, respectively. The negative value of $\Delta \mathrm{H}^{\circ}$ means the exothermal nature of adsorption. The negative amount of $\Delta \mathrm{S}^{\circ}$ indicates that the degree of order increases upon adsorption. The negative value of $\Delta \mathrm{G}^{\mathrm{o}}$ points to the possibility and spontaneity of the adsorption process.

Table 7. Thermodynamic results of LYS on MCM-41@LDH (In optimized conditions).

\begin{tabular}{ccccc}
\hline Equation & $\mathrm{T}(\mathrm{K})$ & $\begin{array}{c}\Delta \mathrm{H}^{\circ} \\
\left(\mathrm{kJ} \mathrm{mol}^{-1}\right)\end{array}$ & $\begin{array}{c}\Delta \mathrm{S}^{\circ} \\
\left(\mathrm{kJ} \mathrm{mol}^{-1}\right)\end{array}$ & $\begin{array}{c}\Delta \mathrm{G}^{\circ} \\
\left(\mathrm{kJ} \mathrm{mol}^{-1} \mathrm{~K}^{-1}\right)\end{array}$ \\
\hline $\mathrm{Y}=2086.4 \mathrm{X}$ & 288.15 & -17346.30 & -0.04 & -17334.90 \\
-4.768 & 298.15 & & & -17334.50 \\
& 308.15 & & & -17334.10 \\
& 318.15 & & & -17333.70 \\
\hline
\end{tabular}

$\mathrm{T}$ : temperature, $\Delta \mathrm{H}$ : enthalpy, $\Delta \mathrm{S}$ : entropy, $\Delta \mathrm{G}$ : Gibbs free energy.

\section{Conclusions}

Numerous adsorbents were presented in the literatures to study LYS adsorption and some of them were described in Table 8. Comparison of our results with other reports shows that the small amount of MCM-41@LDH leads to get equilibration at the short time.

In this research, to increase the adsorption capacity of MCM-41, it was amended via LDH to fabricate MCM-41@LDH. The salts of $\mathrm{Mg}\left(\mathrm{NO}_{3}\right)_{2} .6 \mathrm{H}_{2} \mathrm{O}$ and $\mathrm{Al}\left(\mathrm{NO}_{3}\right)_{3} .9 \mathrm{H}_{2} \mathrm{O}$ were used for the formation of $\mathrm{LDH}$. After synthesis and identification of MCM-41@LDH using different techniques, the strong interaction between LYS and MCM-41@LDH was studied. analysis of ANOVA indicated that solution $\mathrm{pH}$, LYS concentration, amount of MCM-41@LDH, stirrer time, interaction of LYS concentration and amount of support, interactions of $(\mathrm{pH})^{2}$, (LYS concentration) $)^{2}$, and (amount of adsorbent $)^{2}$ are significant parameters. The maximum adsorption of LYS on MCM-41@LDH predicted by CCD was $0.0250 \mathrm{~g}$ of support, LYS concentration of $300 \mathrm{mg} \mathrm{L}^{-1}, \mathrm{pH} 7.50$, and stirrer time of $55 \mathrm{~min}$.

Also, isotherm, kinetic, and thermodynamic analyses for the adsorption of LYS onto MCM-41@LDH were investigated under optimized conditions designed via CCD experiments. Freundlich model displayed excellent fit to the experimental results, which means the LYS adsorption onto MCM-41@LDH was heterogeneous. The adsorption model indicated the second order kinetic with high amount of $\mathrm{q}_{\mathrm{eq}}$, the negative value of $\Delta \mathrm{G}^{\circ}(-17334.5$ $\mathrm{kJ} / \mathrm{mol} \mathrm{K}$ (at $298.15 \mathrm{~K})$ ), the negative value of $\Delta \mathrm{H}$ $(-17346.3 \mathrm{~kJ} / \mathrm{mol})$, and the low amount of $\Delta \mathrm{S}^{\circ}(-0.04$ $\mathrm{kJ} / \mathrm{mol})$. Hence, based on the obtained results, the structure of LYS retains under the adsorption process. Finally, it is hypothesised that the MCM-41@LDH is a good support of chromatography for use in LYS

Table 8. Comparison of LYS adsorption on various adsorbents.

\begin{tabular}{|c|c|c|c|c|c|c|c|c|}
\hline Support & $\begin{array}{l}\text { Kinetic } \\
\text { model }\end{array}$ & $\begin{array}{c}\text { Isotherm } \\
\text { model }\end{array}$ & $\begin{array}{l}\text { Amount of } \\
\text { support }\end{array}$ & $\begin{array}{c}\text { Equilibration } \\
\text { time }\end{array}$ & qeq & $\mathbf{K}_{\mathbf{F}}$ & $\mathbf{n}$ & Reference \\
\hline $\begin{array}{l}\text { Dye-ligand } \\
\text { poly(hydroxyethyl } \\
\text { methacrylate )/chitosan }\end{array}$ & $\begin{array}{l}\text { Second- } \\
\text { order }\end{array}$ & Freundlich & --- & $2 \mathrm{~h}$ & $\begin{array}{c}10.9-123.5 \\
\left(\mathrm{mg} \mathrm{mL}^{-1}\right)\end{array}$ & 43.8 & 1.18 & $(42)$ \\
\hline MCM-41 and SBA-15 & --- & -- & $50 \mathrm{mg}$ & $48 \mathrm{~h}$ & --- & --- & --- & (43) \\
\hline Magnetic particles & --- & --- & $110 \mathrm{mg}$ & $24 \mathrm{~h}$ & -- & --- & -- & (44) \\
\hline MCM-41 & --- & --- & $50 \mathrm{mg}$ & 144 and $180 \mathrm{~h}$ & --- & --- & --- & (26) \\
\hline $\begin{array}{l}\text { Nanomagnetic particles } \\
\text { modified with poly(N- } \\
\text { isopropylacrylamide) }\end{array}$ & --- & Langmuir & $130 \mathrm{mg}$ & $2 \mathrm{~h}$ & --- & --- & --- & $(45)$ \\
\hline $\mathrm{LDH}\left(\mathrm{MgAl}-\mathrm{NO}_{3}^{-}\right)$ & --- & --- & --- & $24 \mathrm{~h}$ & --- & --- & --- & (33) \\
\hline Graphene & --- & Langmuir & $2 \mathrm{mg} \mathrm{mL}^{-1}$ & $3 \mathrm{~h}$ & --- & 2.032 & 2.032 & (46) \\
\hline $\begin{array}{l}\text { Single-walled carbon } \\
\text { nanotubes }\end{array}$ & --- & Langmuir & $2 \mathrm{mg} \mathrm{mL}^{-1}$ & $3 \mathrm{~h}$ & --- & 1.964 & 1.964 & (46) \\
\hline Graphene oxide & --- & Temkin & $2 \mathrm{mg} \mathrm{mL}^{-1}$ & $3 \mathrm{~h}$ & --- & 1.396 & 1.396 & (46) \\
\hline MCM-41@LDH & $\begin{array}{l}\text { Second- } \\
\text { order }\end{array}$ & Freundlich & $25 \mathrm{mg}$ & $55 \mathrm{~min}$ & $\begin{array}{l}144.920 \\
\mathrm{mg} \mathrm{g}^{-1}\end{array}$ & 4.61 & 2.46 & $\begin{array}{l}\text { Present } \\
\text { research }\end{array}$ \\
\hline
\end{tabular}

$\mathrm{K}_{\mathrm{F}}$ and $\mathrm{n}$ : Freundlich coefficients, $\mathrm{q}_{\mathrm{eq}}$ : adsorption capacity at equilibrium $\left(\mathrm{mg} \mathrm{mL}^{-1}\right)$. 


\section{Advanced \\ Materials Letters https://aml.iaamonline.o}

separation.

\section{Acknowledgements}

The authors gratefully acknowledge the support of Yasouj University for this study.

\section{Disclosure statement}

No potential conflict of interest was reported by the authors.

\section{Keywords}

Central composite design; Freundlich isotherm; MCM-41@LDH; Lysozyme.

\section{Received: 1 May 2021 \\ Revised: 28 June 2021 \\ Accepted: 15 July 2021}

\section{References}

1. Rostamizadeh, S.; Nojavan, M.; Aryan, R.; Isapoor, E.; Azad, M.; J. Mol. Catal. A-Chem., 2013, 374, 102 .

2. Shokrollahi, A.; Abbasi, S.; Mohammadpour Shirazi, S.; $A d v$. Mater. Lett., 2020, 11, 20081550.

3. Kisler, J.; Daehler, A.; Stevens, G. W.; O’Connor, A. J.; Micropor. Mesopor. Mater., 2001, 44-45, 769 .

4. Washmon-Kriel, L.; Jimenez, V. L.; Balkus Jr, K. J.; J. Mol. Catal. B-Enzym., 2000, 10, 453.

5. Takahashi, H.; Li, B.; Sasaki, T.; Miyazaki, C.; Kajino, T.; Inagaki, S; Micropor. Mesopor. Mater., 2001, 44, 755 .

6. Diaz, J. F.; Balkus Jr, K. J.; J. Mol. Catal. B-Enzym., 1996, 2, 115.

7. Tang, W.; Gao, H.; Ni, D.; Wang, Q.; Gu, B.; He, X.; et al., J. Nanobiotechnol., 2019, 17, 68.

8. Cavani, F.; Trifirò, F.; Vaccari, A.; Catal. Today, 1991, 11, 173.

9. Evans, D. G.; Slade, R. C.; Structural aspects of layered double hydroxides. In: Layered double hydroxides; Springer, 2006.

10. Khan, A. I.; O’Hare, D.; J. Mater. Chem., 2002, 12, 3191.

11. Rives, V.; Layered double hydroxides: present and future; Nova Publishers; 2001.

12. Manasse, E.; 1915, 24, 92

13. Zümreoglu-Karan, B.; Ay, A.; Chem. Pap., 2012, 66, 1.

14. Kuthati, Y.; Kankala, R. K.; Lee, C.H.; Appl. Clay Sci., 2015, 112113,100 .

15. Mishra, G.; Dash, B.; Pandey, S.; Appl. Clay Sci., 2018, 153, 172.

16. Saleh, T. A.; Desalin. Water Treat., 2016, 57, 10730.

17. Saleh, T. A.; Environ. Technol. Innovation, 2020, 20, 101067.

18. Saleh, T. A.; Trends in Environ. Anal. Chem., 2020, 28, e00101.

19. Lee, C. H.; Lin, T. S.; Mou, C. Y.; Nano Today, 2009, 4, 165.

20. Willner, I.; Baron, R.; Willner, B.; Biosens. Bioelectron., 2007, 22, 1841.

21. El-Boubbou, K.; Schofield, D.A.; Landry, C. C.; J. Phys. Chem. C, 2012, 116, 17501 .

22. Zhou, Z.; Hartmann, M.; Chem. Soc. Rev., 2013, 42, 3894.

23. Popat, A.; Hartono, S. B.; Stahr, F.; Liu, J.; Qiao, S. Z.; Lu, G. Q.; Nanoscale, 2011, 3, 2801.

24. Fried, D. I.; Brieler, F. J.; Fröba, M.; ChemCatChem, 2013, 5, 862

25. Li, S.; Mulloor, J. J.; Wang, L.; Ji, Y.; Mulloor, C. J.; Micic, M.; et al., ACS Appl. Mater. Inter., 2014, 6, 5704.

26. Katiyar, A.; Ji, L.; Smirniotis, P. G.; Pint, N. G.; Micropor. Mesopor. Mater., 2005, 80, 311.

27. Kresge, C.; Leonowicz, M.; Roth, W. J.; Vartuli, J.; Beck, J.; Nature, 1992, 359, 710 .

28. Ebrahimi, F.; Ph. D. Thesis. Iran , Yasouj: Yasouj University, Faculty of Science, Department of Chemistry; December 2017.

29. Sharifi, M.; Shokrollahi, A.; Ebrahimi, F.; Int. J. Environ. Anal. Chem., 2021, Inpress, https://doi.org/10.1080/03067319.2021. 1928098.

30. Saleh, T. A.; J. Water Supply: Res. Technol.-AQUA, 2015, 64, 892.

31. Hanrahan, G.; Lu, K.; Crit. Rev. Anal. Chem., 2006, 36, 141.

32. Hamzah, Z.; Narawi, N.; Rasid, H. M.; Yusoff, A. N. M.; Malaysian J. Anal. Sci., 2012, 16, 290.
33. Yang, Q.-Z.; Chang, Y.-Y.; Zhao, H.-Z.; Water Res., 2013, 47, 6712.

34. Shafe, A.; M. Sc. Thesis. Iran, Yasouj: Faculty of Science, Department of Chemistry, Yasouj University; February 2018

35. Shen, J. L.; Lee, Y. C.; Lui, Y. L.; Cheng, P. W.; Cheng, C. F.; J. Physics: Condens. Matter, 2003, 15, L297.

36. Alansi, A. M.; Qahtan, T. F.; Saleh, T. A; Adv. Mater. Interfaces. 2021, 8, 2001463.

37. Mazloum-Ardakani, M.; Sheikh-Mohseni, M. A.; AbdollahiAlibeik, M.; Benvidi, A.; Analyst, 2012, 137, 1950.

38. Grigoropoulou, G.; Stathi, P.; Karakassides, M. A.; Louloudi, M.; Deligiannakis, Y.; Colloid. Surface. A, 2008, 320, 25.

39. Vinu, A.; Gokulakrishnan, N.; Balasubramanian, V. V.; Alam, S.; Kapoor, M. P.; Ariga, K.; et al., Chem. Eur. J., 2008, 14, 11529.

40. Saleh, T. A; J. Cleaner Prod., 2018, 172, 2123.

41. Ho, Y. S.; McKay, G.; Process Biochem., 1999, 34, 451

42. Bayramoğlu, G.; Yılmaz, M.; Arıca, M. Y.; Biochem. Eng. J., 2003, 13,35 .

43. Yang, J.; Daehler, A.; Stevens, G. W.; O'Connor, A. J.; Stud. Surf. Sci. Catal., 2003, 146, 775.

44. Peng, Z.; Hidajat, K.; Uddin, M.; Colloids Surf. B, 2004, 35, 169.

45. Shamim, N.; Liang, H.; Hidajat, K.; Uddin, M.; J. Colloid Interface Sci., 2008, 320, 15.

46. Smith, S. C.; Ahmed, F.; Gutierrez, K. M.; Rodrigues, D. F.; Chem. Eng. J., 2014, 240, 147. 